UDC 378.064.2:316.454.52:172.16

DOI https://doi.org/10.32840/1992-5786.2020.73-2.40

L. O. Sushchenko

Doctor of Pedagogical Sciences, Professor, Head of the Department of Preschool and Primary Education

Zaporizhzhia National University

O. E. Hrybanova

Candidate of Pedagogical Sciences, Top-Rank Teacher,

Head

College of Economics and Management of the Zaporizhzhia National University

A. V. Khodakovska

PhD Student at the Department of Preschool and Primary Education Zaporizhzhia National University

\title{
EDUCATIONAL DIALOGUE AS A FACTOR OF EFFICIENT HUMANISTICALLY-ORIENTED TEACHER-STUDENT INTERACTION
}

The article presents a research on the scientific principles of organizing educational dialogue seen as a factor of successful humanistically-oriented teacher-student interaction in the current context.

It is substantiated that in modern information society the problem of communication is of utmost importance, and humanistic and democratic reform of the education system, its transition from subject to personality-oriented learning can create conditions for self-development and self-realization of the individual in the educational process. To provide the efficiency of this transition we should analyse the training of future professionals and find the ways to improve it.

The study examines the notion of dialogue as a primary, generic form of human communication. It is considered a priority factor of personality development, principle and method of studying personality, a creative process that unfolds according to its own laws with its own internal dynamics; primary mental state that unfolds in interpersonal communication space.

It is proved that professional and pedagogical communication is the main form of educational process organization, the productivity of which is determined by the goals and values of communication.

The research shows that professional training should be based on ethical and humanistic laws and principles; humanistically-oriented training of future specialist is a prerequisite for effective professional activity. The specificity of such training is based on the principles of dialogical interaction with an individual with his or her original and unique attitude placed in the centre.

It is proved that dialogue should be humanistically-oriented, and the teacher, communicating with the students, should try to understand and accept their position or objectively find out the reasons for its rejection. The teacher's pedagogical paradigm is to understand the development of personality as a movement from the ability to listen and understand other "voices" to the ability to dialogue with it, to doubt, to search for the truth together and to be open to multiple subjects. The humanity of dialogic communication presupposes equality of positions, altruistic and empathic features of a teacher's personality: respect for the thoughts, actions and deeds of the students, trust in them, empathy, ability to see a partner in educational process. Dialogue presents a direct movement from the people's needs to the unknown direction of their thinking and backwards: from the dynamics of thought - to the dynamics of behaviour - a particular personal activity. It is substantiated that involvement of students in various forms of dialogic interaction in educational process creates opportunities for the formation of a communicative personality of future specialist. It also contributes to the development of activity-oriented teachers and students, their interpenetration into world of feelings and experiences, readiness to accept interlocutors and interact with them.

Key words: dialogue, educational dialogue, interaction, humanism, communicative personality.

Problem statement. Socio-economic changes, reforming the education system on humanistic and democratic principles, the transition from subject to personality-oriented learning create conditions for self-development, self-realization of the individual in educational process, the effectiveness of which is impossible without a detailed analysis of training and finding ways to improve the process.
The analysis of the practices of higher educational institutions allows us to assert the priority of the informative and descriptive nature of education and, as a consequence, we get future specialists who are passive performers of professional functions. Such organization of educational process generates formalism and negatively affects the quality of training. 
Analysis of recent research and publications. Student-oriented pedagogical process and humanistic character suggest, first of all, the development of dialogic consciousness and thinking, dialogic framework (Sh. Amonashvili, I. Bekh, V. Bibler, I. Ziaziun, S. Kurganov, V. Litovskyi, A Maslow, K. Rogers, et al.), it helps to resolve the contradictions that exist in pedagogical practice between the creative nature of cognitive activity and the reproductive nature of learning, between the increasing amount of educational information to be processed, and insufficiently effective forms and methods of its transmission.

Today there is a need for such human interaction, which, despite all the differences of views, positions, and attitudes, is based on the principles of dialogic communication, cooperation and co-creation. However, teachers are not always ready to build their relationships with students on a dialogical basis, using educational dialogue as a form of communication, teaching and a means of creative personality development. If a dialogue as a method is used in the classroom, it is often attributed organizational character, rather than pedagogical. A dialogue is hardly ever seen as pedagogical value, a principle, a condition for creative work of teacher and student, self-improvement of their personality.

Therefore, the problem of building educational process on the principles of dialogic communication, cooperation and co-creation is especially relevant.

The purpose of the article is to reveal the scientific principles of the process of organizing educational dialogue as a factor of efficient humanistically-oriented teacher-student interaction.

Material outline. The issues of "dialogue" and its features have been presented in various studies. L. Vygotskyi, P. Halperin, O. Leontiev, S. Rubinstein described the dialogic nature of language and thinking. Dialogue as a form of learning is analysed by V. Andriievska, S. Kurhanov, E. Mashbits, et al. The potential of dialogue as a form of communication, style of interaction, means of mutual influence and mutual understanding is covered by $\mathrm{H}$. Andreieva, O. Bodaliov, A. Dobrovych, I. Ziaziun, H. Sahach, et al.

Analysis of psychological and pedagogical literature shows the lack of clear unambiguous understanding or definitions of such concepts as "dialogue", "dialogic approach", "dialogic communication". Thus, dialogue, on the one hand, is seen as the most democratic form of communication, and on the other, as a type of communication characteristic of certain types of interaction.

Some authors consider dialogue as a direct linguistic communication between two people, emphasizing the specificity of this form of communication, due to the joint efforts of the two agents. Others believe that the interaction of the two agents is not in itself a dialogue; the latter occurs where there is an interaction of two different meaningful positions (they can belong to both interlocutors or one person). Considering the dialogue in different planes, O. Kovalev defines it as:

- a primary, generic form of human communication;

- a leading factor in personal development;

- the principle and method of studying personality;

- a process that unfolds according to its own laws and its own internal dynamics;

- primary mental state that unfolds in the interpersonal communication space;

- the most effective method of pedagogical, psycho-corrective influence;

- a creative process.

Dialogic communication, according to L. Petrovska, is characterized by equality of the parties, subjective position of participants, mutual activity, in which everyone not only feels the influence, but also equally influences the other by mutual penetration of partners into the world of feelings and experiences, willingness to join the point of view of the other party, the desire for complicity, and empathy [1].

O. Hoikhman notes that "dialogue is a process of mutual communication, when the cue is replaced by the appropriate phrase and there is a constant change of roles" [1]. He identifies a number of conditions for dialogue between the partners of language communication: the initial gap in knowledge, the need for communication, determinism, i.e. following causal relations framework - shared memory, general language knowledge, semantic coherence of dialogue.

L. Zazulina claims that dialogical form of education gives each student the opportunity to express themselves, present their opinion. In a dialogue, the so-called dialogical relations are of great importance. M. Bakhtin convincingly claims: "Dialogic reaction personifies every statement to which it responds". Dialogue is characterized by "a two-voiced word", as in the replicas of the dialogue, someone else's position is taken into account, they receive a reaction [1].

In general, the efficient training of a future specialist with a high level of professional knowledge and skills suggests "humanity" as the highest personal trait. Hence successful professional training involves the unity of training and its humanistic aspect.

Dialogue at the local and global levels is a way of communication and understanding, coexistence of historically different cultures, a means of productive thinking and personal development. Thus, it is the conceptual basis for new education. Studies on the issues of dialogue and dialogicity are extremely diverse. Socrates and Plato saw dialogue as a means of cognition, finding the truth; F. Schleiermacher - as a means of self-awareness, self-knowledge of the individual; M. Buber, K. Jaxpers - as a means of spiritual unity of people and their spiritual enlightenment.

The professional activity of teachers by their nature and outputs should be humanistic, and therefore requires humanistic relations between the agents 
of the educational process. Teaching of humanistic interaction begins in a higher educational institution. But, unfortunately, this problem is covered only in certain modules of psychological and pedagogical courses, information from which is not transferred to other topics, it is not directly introduced into the didactic space of classes.

As practice shows, teachers consider the professional training of students in isolation from the humanistic paradigm of the education system or pay attention only to the formation of humanistic knowledge. This is because dialogic interaction is insufficiently used in the educational process. Though, it can promote the development of empathy and perceptiveness in students, helps and determines value choices, forms in them the ability to solve pedagogical problems, helps to reflect and evaluate attitudes.

There is no place for passive presence in dialogic communication. Its participants are partners, interlocutors who are united by a common motive of activity and are connected by relations of co-authorship, mutual support and mutual assistance. Dialogue is impossible without freedom of all its participants. Therefore, a productive dialogue requires from the teacher a respectful attitude to the opinion of each student, a willingness to join their point of view, a critical understanding of their own position. The teacher must accept the right of the individuals to their opinions, to erroneous judgments, emphasizing in such a situation the importance of the students' thoughts.

Professional training should be based on ethical and humanistic laws and principles, and for the pedagogical aspect of humanism it is advisable to use the term "humaneness". Humanism and humaneness have different semantic functions: the main social function of humanism is to arm civilization with the values of mankind and focus on the best (beauty, will, feelings), and the pedagogical function of humaneness - the orientation of man to his duty to be human.

In individuals, humanism is realized through humaneness as its main quality, which is based on moral norms and values (person, group, living being), and in human consciousness it is represented in the experience, compassion, and in activities implemented in acts of assistance, and complicity.

Humanistically-oriented training of the future specialist is a prerequisite for effective professional activity. The specificity of such training is based on the principles of dialogical interaction. A person with his or her original and unique attitude is placed in its centre.

Dialogue should be humanistically-oriented and the teacher, communicating with the students, should understand and accept their positions or objectively find out the reasons to explain the rejection. The teachers' pedagogical paradigm is to accept the development of personality as a movement from the ability to listen and understand other people to the ability to interact with them, to doubt, to search for the truth together and to be able to cover numerous aspects. Humaneness of dialogic communication presupposes equality of positions, the presence of altruistic and empathic features of the teacher's personality: respect for the thoughts and actions of the students, trust in them, empathy, ability to see a partner in educational process. In a dialogue one can see a direct movement from practical needs to the new sphere of thinking and the backwards: from the dynamics of thought - to the dynamics of behaviour, i.e. a specific activity of a person.

Educational dialogue is a purposeful, organized interaction of the agents in pedagogical process, based on the principles of cooperation, co-creation, it involves a problem that has different solutions, the desire of students in the process of mutual exchange of ideas to find the best ideas in different answers. The educational dialogue performs an informative, regulating function and provides the developmental nature of learning [3].

Focus on the multifunctionality of communication allows the teacher to organize interaction in and out of classes as a holistic process. Teachers should not be limited to planning only the informational component, they should create conditions for the exchange of attitudes, experiences, help each individual to assert themselves with dignity in the team, ensuring cooperation and co-creation.

Teacher's communication with students is specific, because due to their status they act from different positions: the teacher organizes the interaction, the student perceives and joins it. Teachers need to help their students become active participants of pedagogical process, provide conditions for the realization of their potential, i.e. the subject-subject nature of pedagogical relations.

The subject-subject nature of pedagogical communication is the principle of its effective organization, which suggests equality of psychological positions, mutual humanistic attitude, activity of teacher and students, their interpenetration into the world of feelings and experiences, readiness to accept a interlocutors and interact with them.

The main features of educational dialogue on a subject-subject basis are as follows:

1. Personal orientation of interlocutors - willingness to see and understand the interlocutor, respect to one another. Taking into account everyone's right to choose, we must strive not to impose an opinion, but to help others choose their own way of solving a problem. In a particular situation, this can be done through various techniques.

2. Equality of psychological positions of interlocutors. Although the teacher and students are socially unequal (different life experiences, roles in interaction), to ensure the activity of the latter, to provide the development of students' personality, we should 
avoid the dominance of the teacher and recognize the students' rights to their own opinions and positions, and be ready to change. Students want to be consulted with, they need their opinions to be taken into account, and the teacher's task is to consider these aspects.

3. Penetration into the world of feelings and experiences, readiness to take the position of the interlocutor. A dialogue should be based on the principles of mutual trust, when partners listen to each other, share feelings, and empathize.

4. Non-standard methods in the process of educational dialogue, which is a consequence of moving away from the authoritarian teacher's role.

Conclusions. So, what should the psychological portrait of a personality-oriented HEI teacher be?

The teachers should be open-minded and accessible to any student, not to cause fear, give the students an opportunity to express their thoughts and feelings, frank. The teachers should demonstrate complete trust in students, never humiliate their dignity, be sincerely interested in students' lives, not indifferent to their problems, fair. The teachers should show empathic understanding, i.e. see the behaviour of the future specialists with their own eyes, be able to "wear someone else's shoes", feel the student's inner world and provide real help.

As we can see, the main thing for teachers is value potential, whether they have, according to V. Sukhomlynskyi, a focus on individual, an ability to respect and love others.

Thus, the involvement of students in various forms of dialogic interaction in the learning process provides not only the opportunities for the formation of a communicative personality of future specialist, it also contributes to the efficiency of teacher-student interaction, enables their interpenetration into the world of feelings and experiences, develops readiness to accept an interlocutor.

\section{References:}

1. Volkova N.P. Professional and pedagogical communication: textbook. Kyiv : VC "Academy", 2006. $256 \mathrm{p}$.

2. Bidenko E. Dialectics of formation of the axiological platform of personality in the pedagogical process. Higher education in Ukraine. № 3. 2020. P. 72-78.

Сущенко Л. О., Грибанова О. Є., Ходаковська А. В. Навчальний діалог як чинник успішної гуманістично зорієнтованої взаємодії викладача і студента

У статті презентовано та проаналізовано наукові засади процесу організації навчального діалогу як чинника успішної гуманістично зорієнтованої взаємодії викладача і студента за умов сьогодення.

Обгрунтовується, що в сучасному інформаційному соціумі проблема комунікації є пріоритетною й актуальною, а реформування системи освіти на гуманістичних і демократичних засадах, перехід із предметного на особистісно-орієнтоване навчання створюють умови для саморозвитку, самореалізації особистості в освітньому процесі, результативність якого неможлива без детального аналізу процесу професійної підготовки майбутніх фрахівців і пошуку шляхів її подальшого вдосконалення.

У дослідженні діалог розглядається як первинна, родова форма людського спілкування; пріоритетний чинник розвитку особистості; принцип і метод вивчення особистості; процес, що розгортається за своїми законами та власною внутрішньою динамікою; первинний психічний стан, що розгортається в міжособистісному просторі спілкування; творчий процес.

Доведено, що професійно-педагогічна комунікація $\epsilon$ основною фрормою організації освітнього процесу, продуктивність якого зумовлена цілями і цінностями спілкування.

3'ясовано: профресійна підготовка має грунтуватися саме на етико-гуманістичних законах і принципах; гуманістично зорієнтована підготовка майбутнього фрахівия є передумовою ефрективної профресійної діяльності; специфікою такої підготовки є те, що вона будується на засадах діалогічної взаємодії, в центрі якої - особистість із їі самобутнім та унікальним ставленням до навколишнього світу, інших людей.

Доведено, що діалог має бути гуманістично зорієнтованим, коли викладач, спілкуючись зі студентом, намагається зрозуміти та прийняти його позицію або ж об'єктивно з'ясувати причини ії неприйняття. Педагогічна парадигма викладача полягає в розумінні розвитку особистості як руху від уміння слухати і розуміти інші «голоси» до вміння вести з нею діалог, сумніватися, здійснювати спільний пошук істини й бути відкритим множині суб'єктів. Гуманність діалогічного спілкування передбачає рівноправ'я позицій, наявність альтруїстичних та емпатійних особливостей особистості викладача: повагу до думок, учинків і справ студента, довіру до нього, співпереживання, уміння бачити в партнерові співучасника освітнього процесу. У діалозі відбувається прямий рух від потреб людини до невідомого напряму ї мислення і рух навпаки: від динаміки думки - до динаміки поведінки конкретної діяльності особи. Обгрунтовано: залучення студентів до різноманітних фоорм діалогічної взаємодії в освітньому процесі створює можливості для формування комунікативної особистості майбутнього фрахівця, здатного до активності викладача й студентів, взаємопроникнення їх у світ почуттів і переживань, готовності прийняти співрозмовника, взаємодіяти з ним.

Ключові слова: діалог, навчальний діалог, взаємодія, гуманізм, комунікативна особистість. 